\title{
APPLIED ASPECTS OF THE DISTRIBUTION OF SPENDINGS FOR MANAGEMENT ACCOUNTING AND CONTROL
}

\author{
Anna Kozachenko ${ }^{1}$, Oleksandr Panadiy ${ }^{2}$, Lina Chudak ${ }^{3}$
}

\begin{abstract}
The article deals with questions of distribution of expenses of agricultural producers of goods for the purposes of management accounting and control. Methodology. In the course of the research, the arguments in support of the proof of the managerial nature of accounting of expenses and calculation of the prime cost of agricultural products are advanced. It causes the shift of emphases of management accounting to this section as to one of the key instruments of management of expenses of the agricultural enterprises. Results. Expense management on the basis of accounting tools is the main leverage over the administrative strategy of agrarian producers in the conditions of strengthening of the volatility of the market, aggravation of the competition, and the growing influence of the world prices for products of agricultural production on pricing at the subjects of the agrarian market. At the same time, cost accounting and calculation of product costs make a separate subsystem of management accounting, based on a combination of various elements of a method of accounting. This subsystem consists of its internal divisions and parts, and a segment of cost distribution for the maintenance of machines and equipment of agricultural enterprises is investigated in the article. In particular, the article demonstrates the statement about the discrepancy of the actual state of distribution of these expenses to the order provided by Ukrainian normative and methodical documents in the field of accounting, and the key reasons of this negative phenomenon are being established. The first of such reasons is insignificance of sanctions for violation of accounting legislation, which exists in Ukraine, and the international accounting rules, which according to the established statutory requirements or their own initiative are used by agricultural producers. The second reason lies in an optional character of methodical approaches, developed at the level of the relevant ministries and departments, to the accounting of expenses for cars and the equipment, at the low initiative of accountants with the PostSoviet style of thinking that is fatal to the idea of the reliable distribution of these expenses. Practical implications. To resolve the problem of reliability of information about costs of machines and the equipment negotiated in prime cost of agricultural products (works, services), an automatic algorithm of distribution of these expenses is offered, which is supposed to be realized via the corresponding accounting software. The point of use of the software is caused, on the one hand, by considerable by labour input of the process of accumulation and allocation of costs on the offered algorithm, and on the other hand, by technical capabilities of the agrarian enterprises which, according to data of the last researches in this sphere, point at the almost completed process of automation of accounting in agriculture on the basis of computer accounting programs. Value/originality. The methodological basis of such an algorithm is created by the developed suggestions for improvement of the distribution of costs for machines and equipment maintenance by ensuring the personified accounting of expenses on every object of these means of labour. It is proposed to carry out the further distribution of accumulated expenses on direct fuel consumption expenses on these objects when using active machines and mechanisms in terms of directions of expenditure and in proportion to productivity when using motorless mechanisms.
\end{abstract}

Key words: cost accounting, cost calculation, accounting of machines, equipment accounting, management accounting, control.

JEL Classification: M40, M41, M49, O21

\footnotetext{
Corresponding author:

${ }^{1}$ Vinnytsia National Agrarian University, Ukraine.

E-mail: sergeykozachenko@ukr.net

ORCID: https://orcid.org/0000-0002-8469-7081

${ }^{2}$ National Scientific Center "Institute of Agrarian Economics", Ukraine.

E-mail: alexpanadiy@gmail.com

ORCID: https://orcid.org/0000-0002-4771-812X

${ }^{3}$ Vinnytsia National Agrarian University, Ukraine.

E-mail: chudaklina@ukr.net

ORCID: https://orcid.org/0000-0002-9687-5148
} 


\section{Introduction}

According to standard approaches, cost accounting and control and cost calculation are the main elements of management accounting. This is justified since the official cost accounting documents in international and Ukrainian accounting systems do not include precise step-by-step algorithms for such accounting and cost distribution. Even the most creative accountant will find such algorithms neither in the domestic Accounting Standard 16 Costs nor in the International Accounting Standard 2 Inventories.

This means that the functions and full powers of developing the methods of accounting and costing calculation in some enterprises are their own prerogative. That is why these questions belong to the field of managerial accounting as a direct complement to standardized accounting.

However, the influence of the Soviet and post-Soviet system of social relations, which shows itself in the reluctance of domestic accountants to develop their own accounting and calculation methods, which is based on the expectation that such a state will provide such development, results in the official methodological instructions issued by various ministries and other executive bodies in Ukraine with regard to cost accounting and costing calculation. However, today, more and more large enterprises start to work on the development of their own methods of accounting for costs and calculations.

The methodical recommendations issued by various authorities contain developed and summarized on the basis of the research of achievements of best practices approaches to cost accounting and calculation of the cost price of products, works, and services in certain areas of the national economy. These approaches are selected for logic, the stage of public discussion, and further testing at pilot enterprises.

In Ukraine's agriculture, cost accounting and costing of products, works, and services of enterprises of the area are contained in the Methodological Recommendations on Planning, Accounting and Calculation of Pricing of Products, Works, and Services of Agricultural Enterprises, which were approved by the Ministry of Agrarian Policy and Food of Ukraine in 2001 (Nakaz Pro zatverdzhennja Metodychnykh rekomendacij z planuvannja, obliku i kaljkuljuvannja sobivartosti produkciji (robit, poslugh) siljsjkoghospodarsjkykh pidpryjemstv, 2001). Implementation of the requirements of these Methodological Recommendations provides the management services of agrarian enterprises with information on the costs of their various re-parts and incisions.

Consequently, at a certain level of experience and organization of accountants, the requirements of the Methodological Recommendations are necessary for their implementation in the day-to-day work of agricultural enterprises. But the question remains whether there is a correlation between the real approaches to cost accounting and agricultural cost accounting in official recommendations. Its relevance is valid given two points, related not only to the accounting but also to the control:

1. The insignificance of fines and other penalties for violating the accounting procedure, which solves the hands of accountants in order not to take care of the implementation of complicated accounting rules in practice.

2. Optional nature of the methodological recommendations, including in terms of cost accounting and calculation of the cost of production, works, services of agricultural enterprises.

\section{A brief overview of the literature}

Management accounting in agriculture in Ukraine in its conceptual positions was the subject of research by such scientists as V. M. Zhuk (Zhuk, 2009), V. B. Mossakovskyi (Mossakovsjkyj, 2013), etc. The accounting and distribution of indirect costs in agricultural enterprises were investigated by J. P. Ishchenko (Ishhenko, 2005), T. Y. Kodimskaya (Kodymsjka, 2013), T. M. Ostapenko (Ostapenko, 2013), O. L. Primachenko (Prymachenko, 2011), etc.Accounting ofmaintenance costs formachinery and equipment was the subject of O. V. Borovich (Borovych, 2009), S. O. Mikhailovina (Mykhajlovyna, Shajko, Oljadnichuk, 2015), L. I. Stadnik (Stadnik, 2015). However, these publications do not include studies on the compliance of the accounting of these costs in agricultural enterprises with methodological requirements and scientific proposals for its improvement.

In foreign practice, among the latest researchers on management accounting in agriculture, it is necessary to distinguish Fatih Abubakar, Zeki Dogan, Lisa Jack, Philipp Johnson, and Nora Zardi. These authors were developing management accounting in the agrarian sphere from sociological, fundamental, and applied positions; however, they do not possess improved methodology and concrete methodical approaches to the accounting of expenses and calculation of product cost, especially in a segment of costs for machines and equipment maintenance. Therefore the purpose of the article is justification of need of putting accounting and distribution of costs for maintenance of machines and equipment of the agricultural enterprises in order which is required by the standards and methodical recommendations on accounting of expenses and calculation of product cost (works, services) in agriculture and also development of suggestions for improvement of this accounting and distribution with identification of expenses on objects of capital assets used for production of agricultural products, for improvement of management and control of prime cost of agricultural products. 


\section{The results of justification of improvement of accounting and distribution of costs for machines and equipment maintenance}

One of the proofs of the reliability of the accounting data on the costs of agricultural enterprises and the cost of agricultural products is a regulation, according to which transfers of the cost of these products carries out costs for the maintenance of working machines and equipment. According to the existing methodological approaches, these costs are spent on the accounts of "Production Costs" and "Total Production Costs".

In the account "Production Costs" in the context of analytical accounts, wages the cost for the maintenance of those funds that are directly used in the production of one particular culture. If machines and equipment are used to grow several crops, the cost of their maintenance is kept on the account of "Total Production Costs". At the same time, the last account is accounting for other costs that cannot be directly attributed to the cost of agricultural products, and existing methodological recommendations for each type of such total production costs include their own separate distribution bases.

For example, for the cost of renting land, the base of distribution is the area of these lands, for the cost of salaries of general staff - direct labour costs for the objects of accounting in the account "Production Costs", etc. For the costs of machines and equipment, such a base is the number of machine-days of work and conditional reference hectares for a machine-tractor park or ton-kilometres for a motor-vehicle park.

But in practice, accountants often do not want to determine the cost of production (works, services) for labour-intensive algorithms. This leads to the fact that all expenses that are subject to distribution are transferred to the cost using a single universal basis. This describes the distortion of cost indicators in the context of objects.

A practical example of the foregoing can be considered the definition of the cost of production of one of the agricultural enterprises of the Kyiv region. This enterprise distributed all indirect costs, including expenses for the maintenance of machinery and equipment, in proportion to the area of agricultural land occupied by the respective crops.

There were no aggregated data on the quantitative indicators of the work of the vehicle fleet and machinetractor park at the enterprise. Therefore, data for the calculation of the amount of distributed costs were used for the article "Fuel and Lubricants" for each crop. The choice of this indicator is grounded on the fact that it more universally characterizes the intensity of the use of machines and equipment.

Therefore, the distribution of the cost of maintaining these machines for fuel consumption is much more logical than for the area in the context of crops. After all, the cultivation of different crops involves a different amount of technological operations. In addition, at the disposal of the same company are often lands of different viscosity, litter, etc.

That is why crops with a much smaller crop area often require much more technology resources than crops with a larger crop area. And this, in turn, is reflected at the level of costs of fuel and lubricants.

The results of the recalculation of costs and the comparison of their sums by crops before and after transfer are presented in Table 1.

This example is far from being unitary. Similar distortions with the wrong choice of distribution centres for indirect costs occurred at the enterprises of Vinnytsia, Kyiv, Odesa, and other regions of Ukraine. Observing this fact, it must be admitted that reliable information on production costs and cost of agricultural products is neither owned by the state nor by owners of agricultural enterprises. It is impossible to solve this problem through administrative means. Ukrainian agricultural enterprises are already overloaded with an excessive number of inspections by official bodies. This leads to the conclusion that in order to ensure the correct allocation of costs to the cost of products (works, services), it should be anticipated in automatic mode. It is possible to realize this by laying the appropriate software algorithms for allocating costs to the accounting products provided for

Table 1

Recalculation of the distribution of costs for maintenance of machines and equipment at the enterprise " $X$ " for crops

\begin{tabular}{|l|c|c|c|c|c|}
\hline Crop & $\begin{array}{c}\text { Amount of actually } \\
\text { distributed costs for } \\
\text { cultivating areas, UAH }\end{array}$ & $\begin{array}{c}\text { The total cost of spent } \\
\text { fuel, UAH (the sum } \\
\text { of direct costs for the } \\
\text { article "PMM" }\end{array}$ & $\begin{array}{c}\text { The share of } \\
\text { distribution by fuel } \\
\text { consumption }\end{array}$ & $\begin{array}{c}\text { The amount of } \\
\text { distributed costs }\end{array}$ & $\begin{array}{c}\text { Onderstatement (-) of } \\
\text { actual costs of crops } \\
\text { compared with the } \\
\text { estimated, UAH (3-5) }\end{array}$ \\
\hline 1 & 2 & 3 & 4 & 5 & 6 \\
\hline Wheat & 743454,19 & 235895,58 & 0,15146772 & 589577,54 & $+153876,65$ \\
\hline Sugar beet & 537155,39 & 393693,53 & 0,252789227 & 983964,45 & $-446809,06$ \\
\hline Sunflower & 1568649,41 & 431946,16 & 0,277351106 & 1079569,85 & $+489079,56$ \\
\hline Soybean & 953645,42 & 451925,60 & 0,290179834 & 1129504,78 & $-175859,36$ \\
\hline Winter barley & 89525,90 & 43937,50 & 0,028212114 & 109813,69 & $-20287,79$ \\
\hline Total & 3892430,31 & 1557398,37 & 1,0 & 3892430,31 & X \\
\hline
\end{tabular}

Source: own calculations 
accounting automation. This offer has sense even for the reason that accounting software, according to scientists, is used by approximately $90 \%$ of accountants of agricultural enterprises (Pavljukovecj, 2014). Given the availability of a clear, automated tool for allocating the cost of crops to accountants, such a distribution will not be a big challenge.

However, in order to implement such automation algorithms, it should be recognized that the current procedure for distributing costs for maintenance of machinery and equipment of agricultural enterprises between the objects of accounting provided for by the methodological documents of the Ministry of Finance of Ukraine also needs to be improved and revised.

Accounting for the costs of maintaining machines and equipment in a generalized manner for all homogeneous objects also does not ensure the accuracy of assigning these costs to the relevant objects of costing. According to the results of the reporting period, various objects of fixed assets have different performance, but for objects of cost accounting, these costs are averaged over the method.

This statement is illustrated quite simply. For example, two tractors of the same capacity are in operation at the plant, but one of them is domestic, and the other one is imported. The monthly amount of expenses for maintenance of the tractor purchased abroad is $30000 \mathrm{UAH}$, domestic - $7000 \mathrm{UAH}$. At the same time, for a particular reporting month, the purchase of a tractor abroad had a production of 500 hectares, and domestic 600 hectares. The works were carried out: under the crop of wheat -300 hectares, under corn crops -200 hectares, soybean crops -600 hectares. The costs of maintenance of tractors were carried out on a separate subaccount of the account "Total Production Costs" and carried by the objects of cost accounting in proportion to the conditional reference hectares (Table 2).

According to the results of the analysis of the production of these machines, according to the summary data of the work of the machine-tractor park, it was established that the imported tractor has performed on works on wheat 100 hectares, on works on corn - also 100 hectares, on soybeans - 300 hectares. If the maintenance costs of these machines were distributed among crops in proportion to the production of each of the cars, the rates of these costs would be (Table 3 ).

According to the data of the table, the sum of costs on the supply of agrimotor compared with the first variant (Table 2) differs a lot. When distributing costs with its identification on each agrimotor, there is also distribution of costs on maintenance of machines, for instance, on wheat are 13169-10101=3068 UAH by more accurate distribution than by general.

How is it possible to provide with the more exact distribution of costs on the maintenance of machines and equipment?

Accountants should open "Total Production Costs" sub-account "Maintenance of machines and equipment", in its limits-analytical cards-accounts on each object of the main means. These cards-accounts are suggested to be elaborated in such structure:

1. First table: it accumulates the costs of maintaining each specific machine in a layer of expenses (depreciation, repair costs, other maintenance costs).

2. Second table: the display of fuel consumption by machine (mechanism) in terms of directions of fuel

Table 2

Distribution of costs for maintenance of tractors

\begin{tabular}{|c|c|c|c|}
\hline Crop & $\begin{array}{c}\text { Amount of completed works, } \\
\text { hectares }\end{array}$ & $\begin{array}{c}\text { Percentage of distribution on } \\
\text { conditional reference hectares, \% }\end{array}$ & $\begin{array}{c}\text { Distribution of expenses for the } \\
\text { maintenance of a tractor, UAH }\end{array}$ \\
\hline 1 & 2 & 3 & 4 \\
\hline Wheat & 300 & 27,3 & $\mathbf{1 0 1 0 1 , 0 0}$ \\
\hline Corn & 200 & 18,2 & $\mathbf{6 7 3 4 , 0 0}$ \\
\hline Soybean & 600 & 54,5 & $\mathbf{2 0 1 6 5 , 0 0}$ \\
\hline Total & 1100 & 100,0 & $\mathbf{3 7 0 0 0 , 0 0}$ \\
\hline
\end{tabular}

Source: own calculations

Table 3

Distribution of costs for maintenance of tractors with identification of costs for each of them

\begin{tabular}{|c|c|c|c|c|c|c|c|}
\hline \multirow[b]{2}{*}{ Crop } & \multicolumn{3}{|c|}{ Imported agrimotor } & \multicolumn{3}{|c|}{ Domestic agrimotor } & \multirow[b]{2}{*}{$\begin{array}{l}\text { Total costs, } \\
\text { UAH }(4+7)\end{array}$} \\
\hline & $\begin{array}{c}\text { Amount of } \\
\text { completed } \\
\text { works, master } \\
\text { hectares }\end{array}$ & $\begin{array}{c}\text { Percentage of } \\
\text { distribution, \% }\end{array}$ & $\begin{array}{c}\text { Sum of } \\
\text { distributed } \\
\text { costs, UAH }\end{array}$ & $\begin{array}{c}\text { Amount of } \\
\text { completed } \\
\text { works, master } \\
\text { hectares }\end{array}$ & $\begin{array}{c}\text { Percentage of } \\
\text { distribution, \% }\end{array}$ & $\begin{array}{c}\text { Sum of } \\
\text { distributed } \\
\text { costs, UAH. }\end{array}$ & \\
\hline 1 & 2 & 3 & 4 & 5 & 6 & 7 & 8 \\
\hline Wheat & 200 & 40,0 & 12000,00 & 100 & 16,7 & 1169,00 & 13169,00 \\
\hline Corn & 100 & 20,0 & 6000,00 & 100 & 16,7 & 1169,00 & 7169,00 \\
\hline Soybean & 200 & 40,0 & 12000,00 & 400 & 66,6 & 4662,00 & 16662,00 \\
\hline In all & 500 & 100,0 & 30000,00 & 600 & 100,0 & 7000,00 & 37000,00 \\
\hline
\end{tabular}

Source: own calculations 
consumption (directions of work execution). This accumulation is required to determine the proportion of distribution of costs from Table 1 between cost accounting objects. Fuel costs are easily tracked according to the records of tractor drivers, combine harvesters' records, truck traffic letters, passenger car travel letters.

3. Third table: displays the amounts of distributed costs from Table 1 according to the proportions defined in Table 2, with corresponding allocation of expenses from the account "Total Production Costs" to the accounts of expenses accounting for the objects that were consumers of the services of these machines.

\section{Conclusions}

The results of the study carried out in this article indicate the following:
1. The current practice of distributing the costs of maintaining machines and equipment in agrarian enterprises does not correspond to the rules established by the Ministry of Finance of Ukraine.

2. The distorted distribution of costs for the maintenance of machines and equipment of agricultural enterprises distorts the cost of agricultural products, which leads to the unreliability of this information, which is provided for management at the level of the enterprise and the state.

3. The current procedure for distributing the costs of maintenance of machines and equipment between the objects of accounting has its disadvantages since it does not provide for the exact assignment of costs for the maintenance of specific machines and mechanisms precisely at those facilities where the actual use of these machines took place.

\section{References:}

Borovych, O. V. (2009). Udoskonalennja metodyky obchyslennja obsjaghu mekhanizovanykh robit ta pervynnogho obliku roboty mashynno-traktornogho parku [Improvement of the methodology for calculating the volume of mechanized works and the initial accounting of the work of the machine-tractor park]. Visnyk ZhDTU, 1(47), 163-165.

Derzhavna sluzhba statystyky Ukrainy (2018). Rivenj rentabeljnosti vyrobnyctva siljsjkoghospodarsjkoji produkciji $v$ siljsjkoghospodarsjkykh pidpryjemstvakh [The level of profitability of agricultural production in agricultural enterprises]. Retrieved from: http://www.ukrstat.gov.ua

Ghrabovecjkyj, B. Je. (2011). Finansovyj analiz ta zvitnistj: navchaljnyj posibnyk [Financial Analysis and Reporting: tutorial]. Vinnycja: VNTU. (in Ukrainian)

Zhuk, V. M. (2009). Konceptualjni zasady rozvytku upravlinsjkogho obliku v aghrarnomu sektori ekonomiky [Conceptual basis of the development of managerial accounting in the agrarian sector of the economy]. Strateghija rozvytku Ukrajiny, 1-2, 437-441.

International accounting standard 2 «Inventories». Retrieved from: http://ec.europa.eu/internal_market/ accounting/docs/consolidated/ias2_en.pdf

Ishhenko, Ja. P. (2005). Neprjami vytraty na pidpryjemstvakh APK: metody obliku ta porjadok rozpodilu [Indirect costs at APC enterprises: accounting methods and distribution procedures]. Oblik i finansy APK, 3, 24-31.

Kodymsjka, T. Ju. (2013). Shljakhy pokrashhennja obliku ta rozpodilu zaghaljnovyrobnychykh vytrat na pidpryjemstvakh [Ways to improve accounting and distribution of total manufacturing costs in enterprises]. Ekonomika: realiji chasu, 1(6), 196-200.

Ministerstvo aghrarnoji polityky Ukrajiny. Nakaz Pro zatverdzhennja Metodychnykh rekomendacij z planuvannja, obliku i kaljkuljuvannja sobivartosti produkciji (robit, poslugh) siljsjkoghospodarsjkykh pidpryjemstv vid 18.05.2001. № 132 [Ministry of Agrarian Policy of Ukraine. Orders on approval of the Methodical recommendations on planning, accounting and calculation of the cost of agricultural products (works, services) May 18, 2001 № 132]. Retrieved from: http://search.ligazakon.ua/1 doc2.nsf/link1/FIN2842.html

Ministerstva finansiv Ukrajiny. Nakaz Pro zatverdzhennja polozhennja (standartu) bukhghaltersjkogho obliku 16 «Vytraty» vid 31.12.1999 № 318 [Ministry of Finance of Ukraine. About the statement of accounting (accounting) standard 16 «Expenses» December 31, 1999 № 318]. Retrieved from: http://zakon5.rada.gov.ua/laws/show/z0027-00

Mossakovsjkyj, V. B. (2013). Osoblyvosti upravlinsjkogho obliku v siljsjkoghospodarsjkykh pidpryjemstvakh [Features of management accounting in agricultural enterprises]. Ekonomika APK, 6, 40-45.

Mossakovsjkyj, V. B. (2006). Upravlinsjkyj oblik ta jogho osoblyvosti u siljsjkomu ghospodarstvi [Management accounting and its features in agriculture]. Oblik $i$ finansy APK, 1, 129-138.

Mykhajlovyna, S. O., Shajko, O. Gh., \& Oljadnichuk, N. V. (2015). Bukhghaltersjkyj oblik vytrat na mashynnotraktornyj park siljsjkoghospodarsjkykh pidpryjemstv ta udoskonalennja jogho dokumentaljnogho zabezpechennja [Accounting of expenses for the machine-tractor park of agricultural enterprises and improvement of its documentary support]. Aktualjni problemy ekonomiky, 8, 372-380.

Ostapenko, T. M. (2013). Interpretacija prjamykh ta neprjamykh vytrat dlja cilej kaljkuljuvannja [Interpretation of direct and indirect costs for calculation purposes]. Ekonomika. Upravlinnja. Innovaciji, 10. Retrieved from: http://nbuv.gov.ua/UJRN/eui_2013_2_61

Pavljukovecj, M. P. (2014). Koncepcija pobudovy suchasnoji systemy obliku na siljsjkoghospodarsjkomu pidpryjemstvi v umovakh internet-tekhnologhij [The concept of building a modern accounting system at an agricultural enterprise in the conditions of Internet technologies]. Oblik i finansy, 2(64), 66-70. 
Prymachenko, O. L. (2011). Orghanizacija obliku zaghaljnovyrobnychykh vytrat na siljsjkoghospodarsjkykh pidpryjemstvakh [Organization of accounting for total production costs at agricultural enterprises]. Proceedings of the Formuvannja rynkovoji ekonomiky (Ukrainian, 2011) (eds. O. O. Bjeljajev). Kyiv: KNEU.

Stadnik, L. I. (2015). Oblik vytrat i vykonannja robit avto- i mashynno-traktornogho parku siljsjkoghospodarsjkykh pidpryjemstv [Cost accounting and performance of works of automobile and machine-tractor park of agricultural enterprises]. Formuvannja rynkovoji ekonomiky, 33, 669-675.

Ukraina-2015: Obvalnoe padenie rentabelnosti selskogo khozyaystva [Ukraine-2015: The collapse in profitability of agriculture]. Retrieved from: http://nk.org.ua/ekonomika/ukraina-2015-obvalnoe-padenie-rentabelnostiselskogo-hozyaystva-38113

Cyghanova, O. S. Osoblyvosti vyznachennja sobivartosti vantazhnykh avtotransportnykh perevezenj [Features of determining the cost of freight motor transport]. Retrieved from: conference.nuos.edu.ua/catalog/files/.../22162.pdf Abobaker, F. (2013). Understanding the Current Practices of Cost Accounting Systems in the Libyan Agricultural firms: Evidence from Six Libyan Agricultural Firms. International Journal of Scientific and Research Publications, 3, 1-6. Doğan, Zeki, Arslan, Seçkin Köksal, \& Ayşe Gül (2013). Historical development of agricultural accounting and difficulties encountered in the implementation of agricultural accounting. International Journal of Food and Agricultural Economics, 1(2), 105-114.

Jack Lisa (2015). Future making in farm management accounting: The Australian "Blue Book”. Accounting history, 20(2), 158-182.

Jonsson Filip, \& Sandlund Marcus (2017). Farmers' Perception of Management Accounting. Uppsala, p. 54.

Zarda, N. (2009). Development of Management Accounting application at Hungarian agricultural enterprises: abstract of the doctoral (ph. d.) dissertation. Godollo, pp. 12-17. 